EPRA International Journal of Economic and Business Review-Peer Reviewed Journal

Volume - 9, Issue - 5, May 2021 | e-ISSN: 2347 - 9671| p- ISSN: 2349 - 0187

\title{
OCCUPATIONAL MORTALITY AND MORBIDITY AMONG COAL WORKERS AND MINING COMMUNITIES PROXIMATE TO COAL MINING AREAS- A CASE STUDY OF JAINTIA HILLS DISTRICT IN MEGHALAYA
}

\author{
${ }^{1}$ Wistful In Excelsis Nongrem, ${ }^{2}$ Vanlalchhawna \\ ${ }^{1}$ Ph.D Research Scholar, Department of Economics, School of Economics, \\ Management and Information Science, Mizoram University, Tanhril, Mizoram - 796004, India. \\ ${ }^{2}$ Professor, Department of Economics, Mizoram University, Aizawl, Mizoram, India
}

\begin{abstract}
DOI No: 10.36713/epra6381

Article DOI URL: https://doi.org/10.36713/epra6381

The coal sector of Meghalaya provides the rural people and migrants the means of livelihood. It is an artisanal and smallscale mining which obtain minerals illegally. The present study examines the working conditions and conditions of work of coal workers at the mines which endangers the lives of miners daily. The researcher conducted a household survey with a total sample size of 180 households. Data were collected at the household and individual level surveyed from different coal bearing villages. The problems of environmental degradation are a growing concern to the mined and unmined areas yet on the other side the more complex effects are that unscientific mining is also inextricably associated to different health hazards. The result shows that most mining households with 53\% performed work at very deep underground pits of a depth higher than 121 feet below the ground level and $46 \%$ of the households reveals to have work in narrow rat holes which are dug horizontally and the distance of its ranging from 1000-1500 metres. Meanwhile the illegal activity pushes to continue extraction into the remote pristine forests which are far from government hospitals, schools, have no transportation service and complete absence of work safety conduct.
\end{abstract}

KEYWORDS: Informal mining, coal workers, rat-hole mines, mortality, morbidity, health conditions, Jaintia Hills, Meghalaya.

\section{INTRODUCTION AND LITERATURE}

Coal mining in Jaintia Hills is operated by private individuals and works as a family business where some mines are managed by the respective mine owners while some other small mines were leased out to interested investors. Typically, extraction in informal coal mining uses labour intensive methods as workers are not provided of any mechanical devices. Among all other districts of the State, Jaintia Hills is the biggest region to produce coal over the years. Informal mines are known for their unorganised work structures in fact mining work are highly

(c) 2021 EPRA JEBR | EPRA International Journal of Economic and Business Review I www.eprajournals.com 
arduous and dangerous and the impending risk of fire, flood, mine explosion, and cave in can simultaneously cost the lives of many. The nature of mines determines the rate of mine mishaps. Working in underground coal mines may exposed to various health hazards like coal dust, noise, wetness, heat stress, vibration, exposure to radiation, musculoskeletal pain and others (Nongtdu \& Sahu, 2013). In India it is estimated about 1.5 million people in 2007 are directly engaged in the artisanal and small-scale mining (Lahiri-Dutt, 2007). However, it is reported the fatalities of occupational injuries in India's coal mines alone was 200 workers between 2015 to 2017 (Ghosh, 2019). Most of the daily accidents which are either fatal or non-fatal are not reported statistically in official documents and the cause of death are not even known to the concerned families of the coal workers. Informal mines are characterized by low investment capital coupled with no proper mining plans makes these mines to be highly prone to accidents. The rapid increase of human settlements in coal town areas creates a menace for the spread of chronic diseases. As reported by International medical aid organization there was meningitis epidemic in Jaintia Hills District in 2008 with a total of 117 confirmed cases. Few affordable machines that are in use in the hilly mining areas are large cranes which are meant for lifting up the extracted coal or sometimes miners from the deep underground pit. Few workers also used a hand operated coal cutting machine. Apparently, coal workers are not supplied with any kind of Personal Protective Equipment (PPE) thus they work without helmet, safety boots and glasses indicating the negligence of worker's safety. A respirable disease known as the black lung disease or coal worker pneumoconiosis affects most of the underground coal workers caused due to longer work period although low exposure level to coal dust (Liu et al, 2009). Long hours of working, strenuous job, mental harassment, unhealthy habits of smoking and drinking, dusty environment all these cause bodily deformities and degrades overall health. Mining accidents or work-related diseases affects the health and income levels of the households and communities at large as it brings additional burden to the already deprived families.

S. Apam 2014 made an effort to determine the qualitative and quantitative contribution of the small-scale operation to the livelihoods of the rural populations in Amansie, West District of Ghana. He found that the occurrence of infirmity or illness requires appropriate medical treatment in order to stay healthy and in turns improve labourer productivity and maintain a better lifestyle. In case of injuries and sickness at work place poor conditions of road and few hospitals inhibits immediate access of these mining communities to health care services.

Stephens and Ahern 2001 have stated that taking job at coal mines is extremely perilous task around the world. It has short term health effects like injuries and deaths and long-term consequences like suffering from cancer and respiratory diseases called pneumoconiosis, silicosis or asbestosis. Work in deep underground pits causes serious health risks to miners such as heat illness, high blood pressure, chest pain and nervous fatigue. All surface or underground mining produces certain health outcomes which is linked to dust exposure.

Nongtdu and Sahu 2013 have highlighted the poor concern of mining safety and insufficient arrangements regarding accommodation facilities hampers work performance and is also harmful to the workers in coal mines of Meghalaya. They also observed the limited access to basic necessities, no safety equipment, exposure to mining environment leads the coal workers to depression and anxiety disorders. They attributed the prevalence of high rate of accidents and casualties in Jaintia Hills collieries to unscientific mining, unorganised sector and weak governance.

\section{STATEMENTS OF THE PROBLEMS}

Coal owners in Jaintia Hills have not registered their mining activities to the government which makes the State administrators reluctance to deal or address the plight of coal workers in case when incidence of deaths occurred at the accidental sites. Informal mining is a perennial health problem as characterized by the regular supply of cheap labour from various places outside the State who are toiling in the mines without any bonuses, health compensation and social security. The purpose of the study is to examine the impact of coal extraction on the health conditions of the surveyed mining communities.

\section{AREA OF THE STUDY}

Jaintia Hills is divided into two districts namely West and East Jaintia Hills district where most of the coal bearing areas are geographically situated in the eastern Jaintia Hills. According to 2011 Census, Jaintia Hills recorded a population of 392,852 in which the male population was $49.80 \%$ and female population was $50.19 \%$. The population density per square $\mathrm{km}$ is 103 and the sex ratio is 1008 . In terms of literacy rate, Jaintia Hills account for about $63.26 \%$ and it is the only district of Meghalaya where female literacy of $66.71 \%$ is higher than male literacy of $59.75 \%$. As per the reports by the Directorate of Mineral Resources, Government of Meghalaya the production of coal during the year 2011-'12 was 7205.9 ('000 MT), during 2013-'14 was 5732 ('000 MT) 
eventually this is also the year where the National Green Tribunal imposes ban on coal extraction whereas during 2014 -'15 coal production declines to 2521 ('000 MT).

\section{OBJECTIVES OF THE STUDY}

1. To determine the incidence of occupational mortality and morbidity of coal workers in particular and coal mining communities living in and around the mining areas.

2. To examine the health status of coal workers as well as their household members and analyse their sources of medical treatment.

3. To study the socio- economic conditions of coal workers and mining communities in Jaintia Hills district.

\section{METHODOLOGY}

The present study is based on primary data collected from 180 surveyed households with a total of 550 household members using a stratified random sampling method and was carried out during 2016-2018. A structured questionnaire was employed to collect information regarding health and livelihood conditions, socio- economic conditions, the prevalence of mine accidents or deaths of workers engaging in coal sector in last 2 years. Particularly, the technique of interviews, observation method and Focus Group Discussion (FGD) has been conducted to cover other aspects related to coal mining activities. The targeted population comprises of coal mining communities. Logistic regression was used for data analysis and interpretation.

\section{SYSTEMATIC REVIEW ON MINE MISHAPS OR MINE DEATHS AND RELATED CRIMES IN RECENT YEARS IN MEGHALAYA}

Any minerals which is illegally operated give rise to various social crimes. In July 2012 reports revealed about 15 coal workers were trapped in a 100-metre coal pit near Nongalbibra area of South Garo Hills District and no news were received about their whereabouts of the missing workers. The workers were from Dhubri district of Assam (The Shillong Times, 2014). A news report indicated that just in December 2013 at least 11 coal workers died in different coal mining villages of East Jaintia Hills district due to human errors in handling the mechanical equipment or negligence of the imminent danger. It may be noted that in December 6 of 2013 about five coal workers hailing from Assam have died when a crane cable that was used to haul out miners and extracted coal from deep vertical shaft snapped. The other subsequent mine incident occurred on 13 December 2013 where a coal worker identified as Jirmal Bora from Assam died when the crane rope that carried him to the pit broke down. Again, a coal worker identified as Mainul Haque aged 24 from Barpeta in Assam succumbed to his injuries as he was working in Sahkai coal mine a big stone fell on him and he was crushed to death. A worker identified as Emja Wari fell into the coal pit of Warapasa village in Khliehriat and was announced dead at the site while three workers from Nagoan of Assam identified as Masabbir Islam 22, Saidul Rahman 40 and Atabur Haque 25 have been pronounced dead at Briwar colliery due to crane accident. In the same spot two workers also suffered from injuries (The Shillong Times, 2013). Kidnapping and extortion are not uncommon in the coal trade towns of Meghalaya. According to the 2010 report of Impulse an NGO of Shillong estimates around 70,000 children were trafficked from the porous borders of Bangladesh and Nepal to work as bonded labourers in different coal mines of Jaintia Hills (Kharbhih, 2010). In a shocking news report on 24 January 2015 a sub inspector and an officer who was the in charge of Patharkhmah police outpost were killed and their untimely death remain a mystery. The incident occurred after 32 overloaded coal trucks have been detained by him (Majaw, 2016). Meghalayan environmental activist Poipynhun Majaw was murdered on March 2018 at Khliehriat allegedly for agitating the illegal mining in Jaintia Hills (Laitphlang, 2018). A well-known social activist Agnes Kharshiing together with Amita Sangma were brutally attacked by a group of 25-30 people at Tuber Sohshrieh village in East Jaintia Hills district of Meghalaya soon after the woman activist filed a complaint against the ongoing illegal digging and transportation of coal in the region (Lyngdoh, 2018). In 2012 Abdul Karim was badly injured where his limbs are paralysed. The incident happened as he was extracting coal in East Jaintia Hills he got hit by a huge rock on his neck (The Wire, 2018). Within a span of only 59 days that includes from January 22, 2018 to March 21 of 2018 the inspection team seized around 1373 trucks carrying excess coal in which each truck has been overloaded up to 17 Metric tonnes. This may in turn causes several road accidents (The Shillong Times, 2019). One of the most dangerous rat hole mine tragedy occurred at Ksan village on December 13 of 2018 where 15 coal miners or more were trapped inside a pit of 370 feet deep when water of the nearby river Lytein rushed to the narrow tunnels and suffocated the workers but only two persons luckily escaped from the horrified scene (The Hindu, 2019). 


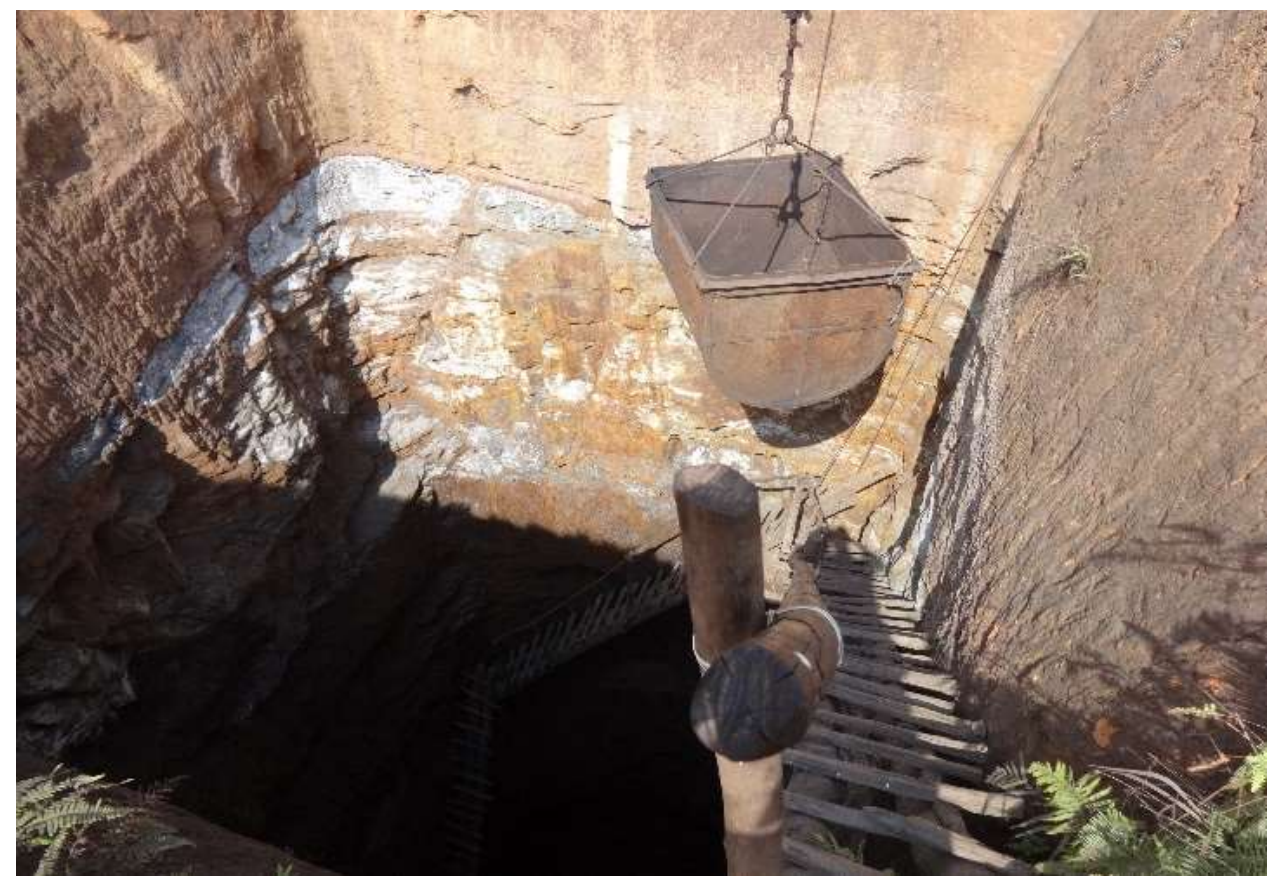

FIGURE 1. An underground coal pit of 100 feet from the surface at Ladrymbai quarry Source: (Field Survey April, 2017).

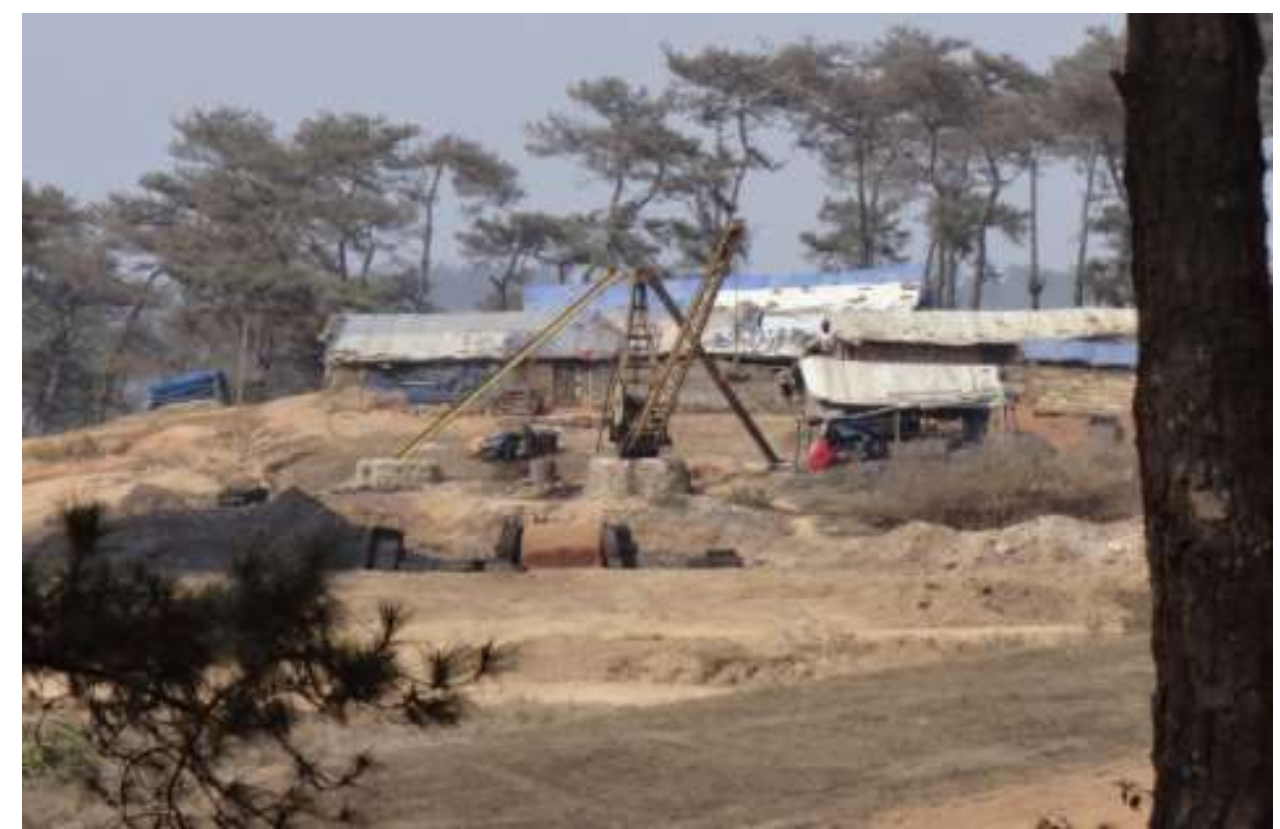

FIGURE 2. Propped up tarpaulin house constructed near coal mining sites at Ladrymbai quarry

Source: (Field Survey April, 2017). 


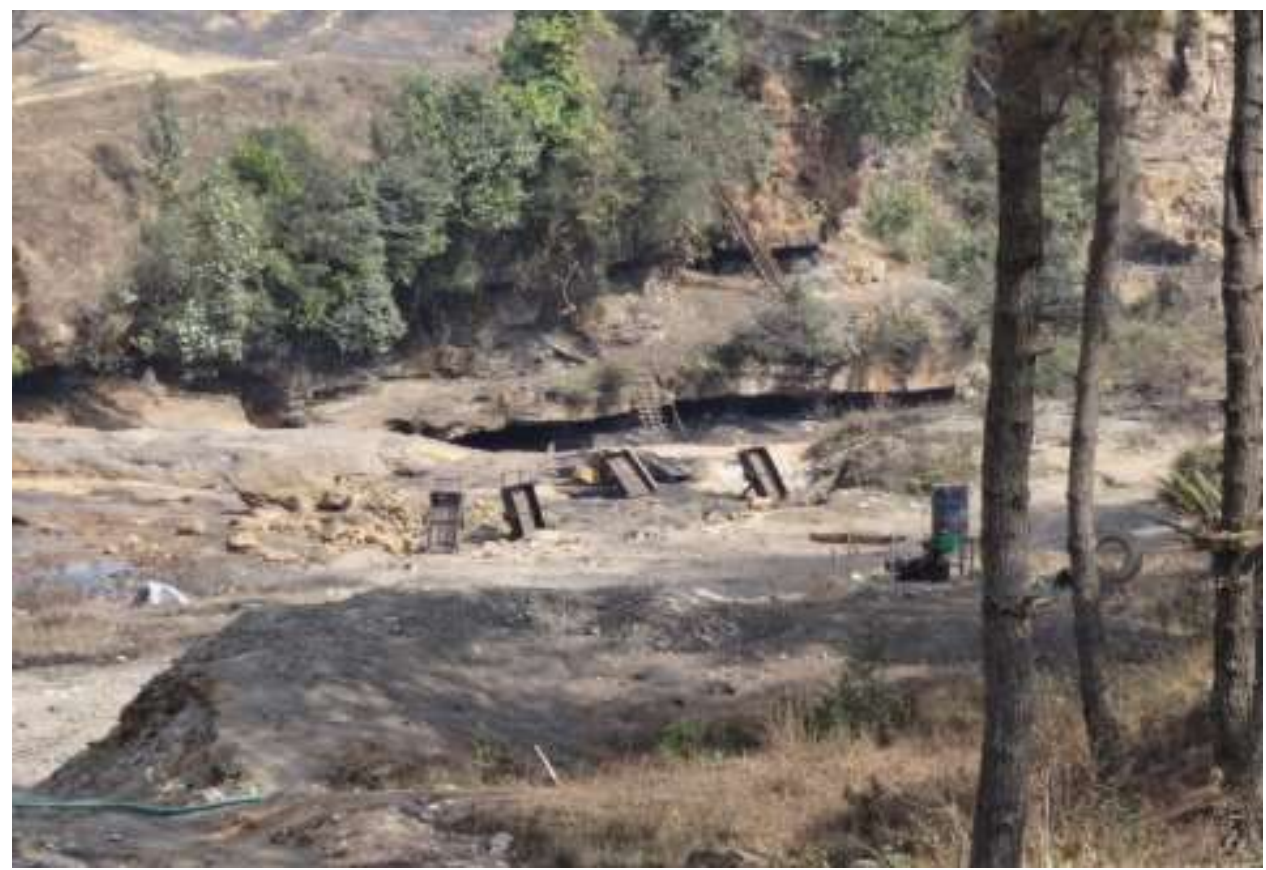

FIGURE 3. Rat holes being dug sideways into the hills of Ladrymbai quarry to reach the coal seams

Source: (Field Survey April, 2017).

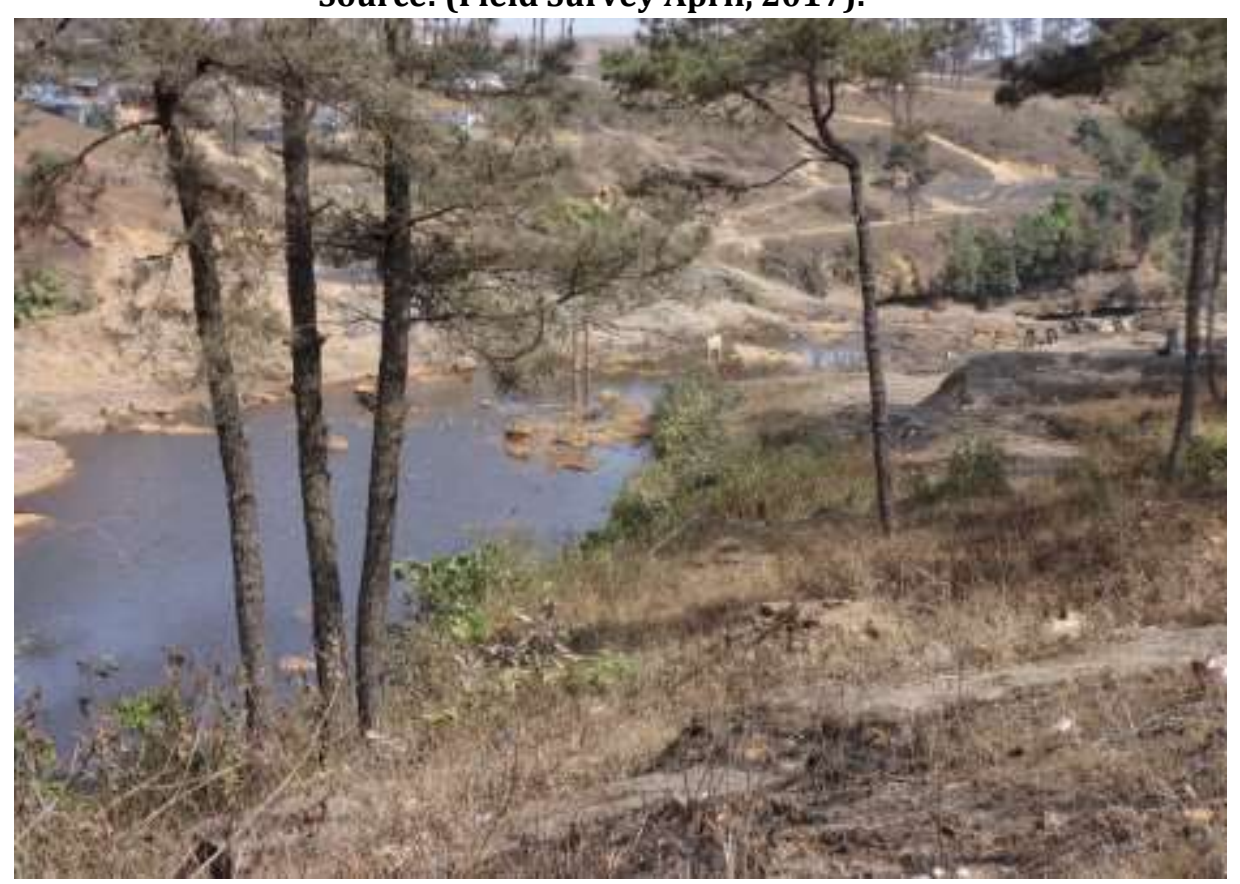

FIGURE 4. Contaminated streams situated near mining areas at Ladrymbai quarry Source: (Field Survey April, 2017).

The local mine owners roughly calculate there are about 1000's active coal mines spread out in Jaintia Hills district alone (Kilsby, 2010). As such coal comes from scattered deposits and in small quantities. The well-known mining coalfields of the region are Bapung, Lakadong, Jarain-Shkentalang, Lumshnong, Malwar-Musiang Lamare, Sutnga, Ioksi. Chyrmang and Mutang. Ladrymbai town is one among the busiest colliery which is also a business centre. Here mining activities are managed by big investors, a visit to the area one will witness across many coal pits 
of the range of 100 to 250 or deeper feet from ground surface. As shown in Figure 1 above the researcher get the chance to enter and examine inside 100 feet mine shaft at Ladrymbai. In the initial stage of mining the workers start with box- cutting, then punctured it till they reach the coal seam of 2-3 feet. The workers used the bamboo ladders to descend to the underground. In the figure a lifting crane is operated to carry coal and workers. In Figure 2 it shows temporary shelters are constructed nearby the mining sites while below ground horizontal tunnels of 1000-2000 metres are dug and what seem to be dismayed is people are staying above. If haphazard mining continues, soil cracks and land sinking is inevitable. In Figure 3 it depicts from sideways on a hill rat holes of 2-3 feet are dug. In order to extract coal, workers literally crawl on their back or stomach. Excavation is done nearby the stream. In Figure 4 it reveals the contaminated stream that is flowing downward and passes through different villages. Coal workers and mining communities used the same water sources for domestic purposes. For drinking water, they have to purchase from their own pockets. The discharge of mining waste into streams and rivers causes acid mine drainage which is extremely harmful to aquatic organisms. As seen in the figure, felling of trees and mass clearance of other vegetation was being done.

\section{RESULTS}

TABLE 1. Output of the multinomial logistic regression at individual level with its coefficients, standard errors (SE), odds ratio (OR) with confidence interval and p-values at $5 \%$ level for relationship between Upper Acute Respiratory (UAR) illness and covariates. Sample size,N=550

\begin{tabular}{lccc}
\hline Variables & $\boldsymbol{\beta}$ (SE) & OR (95\% CI) & p-value \\
\hline Duration of work & & & $.000^{* *}$ \\
10 days - 2 years & $3.292(.895)$ & $26.887(4.656-155.254)$ & $.003^{* *}$ \\
3-5 years & $2.322(.772)$ & $10.191(2.244-46.291)$ & $.000^{* *}$ \\
6-10 years & $2.702(.697)$ & $14.913(3.802-58.499)$ & $.000^{* *}$ \\
Above 11 years & $3.069(.766)$ & $21.518(4.796-96.551)$ & .659 \\
Occupation & & & .740 \\
coal digger & $.301(.681)$ & $1.351(.356-5.133)$ & .137 \\
coal cutter & $.408(1.231)$ & $1.504(.135-16.777)$ & .988 \\
coal breaker & $-1.073(.722)$ & $.342(.083-1.409)$ & $.032^{*}$ \\
coal owner & $12.773(829.204)$ & $3.527 \mathrm{E} 5(.000-. \mathrm{b})$ & - \\
mechanic & $-2.834(1.320)$ & $.059(.004-.781)$ & .185 \\
coal sordar & 0 c & & .484 \\
student & $-.429(.323)$ & $.651(.346-1.227)$ & - \\
unemployed & $-.318(.455)$ & $.727(.298-1.774)$ & - \\
non-miner & 0 c & & - \\
\hline
\end{tabular}

*Statistically significant at $\mathrm{p} \leq 0.05$

${ }^{* *}$ Statistically significant at $\mathrm{p} \leq 0.01$ 
From the study it presents the interpretation of data at individual level of 550 household members. The above Table 1 shows that coal workers who are working more than 11 years are 3.069 times higher the risk of contracting more than one disease of fever, cough, headache or fatigue at a time in relative to not suffering any of the symptoms of UAR illness. It was found to be statistically significant at $p$-value $=.000$ which is lesser than 0.05 . Odds ratio $=$ 21.518 which is greater than 1 indicating greater odds of association between duration of work and increased susceptibility to UAR illness.

Thus, duration of work indicates positive and significant effects in each level which means work exposure for a longer time period is a contributing factor to increased risk of UAR illness. Coal diggers working in underground pits are .301 times higher to suffer more than one disease simultaneously in relative to none. It was not found to be statistically significant at $\mathrm{p}$-value $=.659$ which is greater than 0.05 . Odds ratio $=1.351$ which contains 1 showing no association between the type of mining work and UAR illness.

TABLE 2. Output of the multinomial logistic regression at individual level for relationship between health problems and covariates.

\begin{tabular}{llll}
\hline Variables & $\beta(\mathrm{SE})$ & OR $(95 \% \mathrm{CI})$ & p-value
\end{tabular}

\section{Working days/ week}

$\begin{array}{lccc}\text { 2-3 days } & 3.403(1.188) & 30.066(2.930-308.463) & .004^{* *} \\ \text { 4-5 days } & 2.908(.367) & 18.325(8.920-37.647) & .000^{* *} \\ \text { 6-7 days } & 2.731(.328) & 15.353(8.080-29.175) & .000^{* *}\end{array}$

Age

$1-3$ years

$.948(900.064)$

$2.580\left(.000-.^{c}\right)$

.999

4-12 years

1.177 (900.064)

$3.246\left(.000-{ }^{c}\right)$

.999

13-20 years

.939 (900.064)

$2.557\left(.000-.^{c}\right)$

.999

21-30 years

$1.198(900.064)$

$3.312\left(.000-.^{c}\right)$

.999

$31-65$ years

$1.328(900.064)$

$3.772\left(.000-{ }^{c}\right)$

.999

Above 65 years

$0^{\mathrm{b}} \quad-$

*Statistically significant at $\mathrm{p} \leq 0.05$

${ }^{* *}$ Statistically significant at $\mathrm{p} \leq 0.01$

From above Table 2 coal mine workers who are working for at least 4-5 days in a week are 2.908 times higher of suffering more than one disease or the prevalence of multiple intertwined of malaria, cholera and respiratory problem when compared to none. It was found to be statistically significant at $p$-value $=.000$ which is lesser than 0.05 . Odds ratio $=18.325$ which is greater than 1 showing greater odds of association between number of working days per week and different health outcomes of individual members. Accordingly, working days per week

(c) 2021 EPRA JEBR IEPRA International Journal of Economic and Business Review I www.eprajournals.com 
variable is positive and significant which represents the more days any person laboured in the mines the higher rate of developing health problems.

Working force in the age group of 31 to 65 years are 1.328 times higher likely to suffer more than one disease at the same time relative to none. They are possibly to be afflicted with malaria, tuberculosis or respiratory problems. It was not found to be statistically significant at $\mathrm{p}$-value $=.999$ which is greater than 0.05 . Odds ratio $=$ 3.772 which is greater than 1 denoting greater odds of association with the age of the workers and health complications.

TABLE 3. Output of the multinomial logistic regression at individual level for relationship between Lower Acute Respiratory (LAR) illness and covariates.

\begin{tabular}{cccc}
\hline Variables & $\boldsymbol{\beta}(\mathbf{S E})$ & OR (95\% CI) & p-value \\
\hline Working days/ week & & & \\
2- 3 days & $20.635(3426.383)$ & $9.153 \mathrm{E} 8(.000-. c)$ & .995 \\
$4-5$ days & $3.459(.322)$ & $31.783(16.902-59.763)$ & $.000^{* *}$ \\
6-7 days & $3.013(.283)$ & $20.343(11.686-35.412)$ & $.000^{* *}$ \\
Education & & & \\
Illiterate & $.695(.487)$ & $2.004(.772-5.201)$ & .153 \\
Primary & $.684(.465)$ & $1.982(.796-4.931)$ & .141 \\
Middle & $.014(.511)$ & $1.014(.373-2.759)$ & .979 \\
Matriculate & $.945(.588)$ & $2.573(.813-8.145)$ & .108 \\
Above matriculation & $0^{\mathrm{b}}-$ & - & - \\
\hline
\end{tabular}

-*Statistically significant at $\mathrm{p} \leq 0.05$

${ }^{* *}$ Statistically significant at $\mathrm{p} \leq 0.01$

From above Table 3 it shows that coal communities who are illiterate are .695 times higher of suffering more than one disease at a time relative to none. It was not found to be statistically significant at $p$-value $=.153$ which is greater than 0.05 . Odds ratio $=2.004$ which is greater than 1 thereby denoting greater odds of association with the level of education attained and occurrence of health problems. 
TABLE 4. Output of the multinomial logistic regression at household level for relationship between number of family members suffering, last time suffered and covariates. Sample size, N=180

\begin{tabular}{llll}
\hline Variables & $\beta(\mathrm{SE})$ & OR $(95 \%$ CI $)$ & p-value
\end{tabular}

\section{Structure of house}

$\begin{array}{lccr}\text { Katcha } & 1.938(.788) & 6.943(1.482-32.531) & .014^{*} \\ \text { Semi- pucca } & 2.774(.796) & 16.023(3.367-76.239) & .000^{* *} \\ \text { Pucca } & 2.101(.831) & 8.174(1.605-41.626) & .011^{*} \\ \text { Plastic house } & 0^{\mathrm{b}}- & -\end{array}$

\section{Drinking water}

$\begin{array}{lccc}\text { Contaminated water } & 20.556(.000) & 8.456 \mathrm{E} 8(8.456 \mathrm{E} 8-8.456 \mathrm{E} 8) & - \\ \text { More than 1 problem } & 0^{\mathrm{b}}- & - & \\ \text { Defecation } & & 1.673 \mathrm{E} 8(5.667 \mathrm{E} 7-4.936 \mathrm{E} 8) & .000^{* *} \\ \text { Open toilet } & 18.935(.552) & 3.317(.582-18.918) & .177 \\ \text { Community toilet } & 1.199(.888) & - & -\end{array}$

\section{Duration}

$\begin{array}{lccc}\text { 10 days- 2 years } & 18.949(.000) & 1.697 \mathrm{E} 8(1.697 \mathrm{E} 8-1.697 \mathrm{E} 8) & - \\ \text { 3-5 years } & 2.552(1.116) & 12.833(1.440-114.383) & .022^{*} \\ \text { 6- } 10 \text { years } & 1.019(.577) & 2.771(.895-8.577) & .077 \\ \text { Above } 11 \text { years } & 0^{\mathrm{b}}- & -\end{array}$

*Statistically significant at $\mathrm{p} \leq 0.05$

** Statistically significant at $\mathrm{p} \leq 0.01$

From above Table 4 it reveals that at the household level those mining households who are staying in katcha house are 1.938 times higher to report where 3 to 4 persons in the family are suffering from occupational diseases 
compared to $1-2$ persons. It was found to be statistically significant at $p$-value $=.01$ which is lesser than 0.05 . Odds ratio $=6.943$ which is greater than 1 indicating greater odds of association with the structure of house and number of household members suffering from various illnesses. The structure of house variable indicates positive and significant effects which shows poor housing accounts for the rise in number of sick persons. In terms of drinking water, sampled households reveals contaminated water is the main problem for drinking which is 20.556 times higher in causing at least 1 or 2 among the family members to become sick relative to 5-6 persons. Odds ratio $=$ 8.456 which is greater than 1 therefore showing greater odds of association with the problems of drinking water and number of family members with health risks. Likewise, mining households who are still practising open defecation are 18.935 times higher in reporting either 1 or 2 persons at home likely to fall sick in relative to $5-6$ persons. It was found to be statistically significant at $p$-value $=.000$ which is lesser than 0.05 . Odds ratio $=1.673$ which is greater than 1 thereby denoting greater odds of association with the place to defecate and the number of ailing family members. Positive defecation category shows that consequences of open defecation is related to high rate of morbidity. The duration category shows that head of the household who have been working between 3 to 5 years in coal mines are 2.552 times higher prone to UAR illness within one year rather than in last two years. It was found to be statistically significant at $p$-value $=.02$ which is lesser than 0.05 . Odds ratio $=12.833$ which is greater than 1 thus indicating greater odds of association with the duration of work and the last time the member suffered from Upper Acute Respiratory (UAR) illness.

TABLE 5. Output of the multinomial logistic regression at household level for relationship between treatment expenses, place of medical treatment, rate of accidents and covariates.

\begin{tabular}{llll}
\hline Variables & B (SE) & OR $(95 \% \mathrm{CI})$ & p-value
\end{tabular}

\section{Daily income}

$\begin{array}{lll}\text { Rs } 100-300 & -.770(.000) & .463(.463-.463) \\ \text { Rs 301- } 500 & .075(6215.609) & 1.078\left(.000-.^{\mathrm{c}}\right) \\ \text { Rs 501- } 1000 & 17.924(5580.673) & 6.087 \mathrm{E} 7\left(.000-.^{\mathrm{c}}\right) \\ \text { Above Rs } 1000 & 0^{\mathrm{b}} \quad- & -\end{array}$

\section{Education}

Illiterate

Primary

Middle

Matriculate

Above matriculation

\section{Occupation}

Coal digger

$$
.296(7014.036)
$$

$.454(7014.036)$

Coal cutter

$$
\text { 7.645E6 (.000-. } \left.{ }^{\mathrm{b}}\right)
$$

$$
-.966 \text { (1.108E4) }
$$

$.381\left(.000-.^{b}\right)$

$.464\left(.000-.^{b}\right)$
$-.583(.000)$

$0^{\mathrm{c}}-$
$.558(.558-.558)$
.997 (2) 


\begin{tabular}{|c|c|c|c|}
\hline Coal breaker & $-2.542(7014.036)$ & $.079\left(.000-.{ }^{b}\right)$ & 1.000 \\
\hline Coal owner & $-20.205(.000)$ & 1.679E-9 (1.679E-9- 1.679E-9) & - \\
\hline Mechanic & $18.164(.000)$ & 7.739E7 (7.739E7- 7.739E7) & - \\
\hline Coal sordar & $0^{\mathrm{c}}$ & - & - \\
\hline
\end{tabular}

From above Table 5 it reveals that surveyed households whose daily income is in the range of Rs 501-1000 are 17.924 times higher in medical expenses spending above Rs 5000 relative to within Rs 1000 . It was not found to be statistically significant at $p$-value $=.997$ which is greater than 0.05 . Odds ratio $=6.087$ which is greater than 1 showing greater odds of association with the level of daily income and treatment expenses. The education category indicates those mining households who are illiterate are 15.850 times higher in resorting to self-medication in times of illness relative to more than one sources. It was not found to be statistically significant at $p$-value $=.999$ which is greater than 0.05 . Odds ratio $=7.645$ which is greater than 1 denoting greater odds of association with the level of education attained of household head and place for medical treatment. In the aspect of occupation category, household head who worked as coal digger are .296 times higher of facing accidents frequently at work place rather than rarely. It was not found to be statistically significant at $p$-value $=1.0$ which is greater than 0.05 . Odds ratio $=$ 1.345 which is greater than 1 showing greater odds of association with type of mining work and rate of accidents

TABLE 6. Output of the binary logistic regression at household level for relationship between presence of Lower Acute Respiratory (LAR) illness, death rate and covariates.
Variables
$\beta$ (SE)
OR $(95 \%$ CI $)$
p-value

Drinking water

$13.507(1.453 \mathrm{E} 3)$

$7.343 \mathrm{E} 5(.000-$.

.993

Underground depth $\quad-.714(.245)$

$.490(.303-.792)$

$.004 * *$

* Statistically significant at $\mathrm{p} \leq 0.05$

$* *$ Statistically significant at $\mathrm{p} \leq 0.01$

From above Table 6 it reveals the probability of occurrence of lower acute respiratory morbidity increases with the quality of drinking water. Accordingly, the results also show the odds ratio $=.490$ as the underground coal pits gets deeper. As the depth of coal pits increases in feet, the number of healthy mining communities decreases resulting to premature death.

\section{LIVING CONDITIONS AND LIVELIHOOD}

Due to limited of employment prospects migrant workers are prompted to pursue work at the coal mines. Another section of landless workers from neighbouring villages and districts of Meghalaya are often attracted to take mining work. Discrimination exists as the coal manager assigned the migrant workers to chip coal where seams thickness is low. With coal on their back miners have to climb through the slimy wooden staircases and if unfortunately missed their step can mean death. The rat-hole method of coal extraction in the region created surface cracks and land subsidence as evidenced in some public places or residential structures. Life of the coal miners working in remote locations is depressing since they have to rely on the merchants for the supply of essential food items who may charge twice the market price. Workers and their families usually stayed in damp and crowded propped up tarpaulin house without access to clean sources of drinking water, sanitation facilities like hygienic toilets and electricity. Underground workers are exposed to moisture and humidity which occurred when the water droplets from the mine roofs constantly starts dripping causing in water logging of tunnel floors. 


\section{CONCLUSIONS}

The grave negligence and greed on the part of the mine supervisors can causes a lifelong disability to the poor workers. There are several cases where during rainy season coal workers constantly resume work as they were bothered of the fact that if they are not able to work the entire week, they will not obtain wages. There is no government intervention to check whether the private mine owners follow the safety precautions thus the health and well-being of workers are simply ignored. Among the occupational categories, skilled workers in particular the coal cutter are at a direct risk of cave ins if they are not proficient enough to cut the coal pillar. As per the present study coal breakers mostly females are more susceptible to suffer from tuberculosis. The longer the miners work at the mines the more fragile their health will be. Whenever the workers are injured or felt ill, they practise self-medication rather than to visit the hospital for fear of repercussion of illegal mining. In particular the study indicates about $65 \%$ of the households stated that the district hospital is at least two hours far from their homes and $79 \%$ households reported there is no bus services. All the stakeholders of coal sector must come forward to devise prevention strategies like enforcement of labour laws, give up the primitive mining method, installation of a dust monitoring device and conduct awareness programmes to workers and local residents. In spite of informal coal mining having the potential for creation of rural employment and a means of financial support yet with the onset of mining the rate of crimes like robbery, murdering, land grabbing, gambling, prostitution, alcoholism has increased drastically in the coal rich areas. The role of the government is to address the persistent reasons like extreme poverty, debt bondages and labour trafficking that causes workers to undertake and continue mining work because every individual worker deserves a healthy and long life.

\section{REFERENCES}

1. Apam, S. (2014). Impacts of small- scale mining on rural livelihoods: The Case study of Amansie West district-Ashant, B.A Dissertation. Kwame Nkrumah University of Science and Technology, Kumasi.

2. Ghosh, S. "Rat- hole mines: Negating human lives and ecology”, Mongabay, 8 January 2019.

3. Kharbhih, H. (2010), An Exploratory Study of Children Engaged in Rat Hole Mining in the Coal Mines of Jaintia Hills District, Meghalaya, Impulse NGO Network, Shillong, Meghalaya.

4. Kilsby, R. (2010), Investigation of Child Trafficking in the Coal Mines of Jaintia Hills District, Meghalaya, Impulse NGO Network, Meghalaya, India and Esther Benjamins Trust (EBT), Nepal.

5. Lahiri-Dutt, K. (2007). Roles and status of women in extractive industries in India: Making a place for a gender sensitive mining development. Social Change. 37(4):37-64.

6. Laitphlang, D. (2018): "Social and RTI activist murdered in Meghalaya", Hindustan Times, 20 March.

7. Liu, H., Tang, Z., Yang, Y., Weng, D., Sun, G., Duan, Z. and Chen, J. (2009), "Identification and classification of highrisk groups for Coal Workers' Pneumoconiosis using an artificial neural network based on occupational histories: a retrospective cohort study", The Microbiomes of Humans, Animals, Plants and the Environment, Vol.9: 366, pp.1-8.

8. Lyngdoh, R. (2018): "Activist Kharshiing critical after assault”, Telegraph, 10 November.

9. Majaw, B. (2016): “Ending Meghalaya's "Deadly Occupation”: India's National Green Tribunal's Ban on Rat-Hole Mining”, Verfassung und Recht in Ubersee: Law and Politics in Africa, Asia and Latin America, Vol. 16, Issue I.

10. Nongtdu, P. and Sahu, B.P. (2013), Unorganised Coalmine Workers in Meghalaya, Lakshi Publishers and Distributors, New Delhi.

11. Stephens, C. and Ahern, M. (2001), Worker and Community Health Impacts Related to Mining Operations: A Rapid Review of the Literature.

12. The Hindu. (2019): "Meghalaya mine tragedy: Skeleton of another trapped miner spotted", 25 February.

13. The Shillong Times. (2014): "NGT asks Meghalaya government to file report by April 4: 2012 South Garo Hills mine tragedy", 25 January.

14. The Shillong Times. (2013): "11 coal miners killed in a month in EJH”, 22 December.

15. The Shillong Times. (2019): “CAG raps state government for illegal coal mining, transportation”, 14 September.

16. The Wire. (2018): "Trapped Meghalaya Miners Are the Latest Victims of Years of Labour Exploitation”, 29 December. 